\title{
ANALYSIS OF PEDESTRIAN MOBILITY FACTORS IN MANAUS, BRAZIL
}

\author{
LUÍSA VITÓRIA MENDONÇA DO NASCIMENTO \& JUSSARA SOCORRO CURY MACIEL \\ Federal Center for Technological Education of Amazonas, Brazil
}

\begin{abstract}
Walking as a means of locomotion contributes to pedestrian health, traffic and, hence, the environment. In 230 cities surveyed worldwide, Manaus, in Amazonas, Brazil, is the 125th in the quality-of-life ranking according to global consultancy Mercer, presenting a deficiency in walking practices. Perhaps the reason is related to the lack of adapted public pavements in the peripheral areas of the city, blocked and irregular sidewalks, among others, generated by lack of planning or structure. In addition to structural problems, there is also the climate region issue, which at certain times makes it difficult to commute long walking distances due to high temperatures. Several cities have adopted foot mobility encouragement parameters, such as Portland, in Oregon, US, which has adopted an urban growth boundary, narrower streets and the encouragement of walking and bicycle use. As a result, automotive use was reduced, pedestrian pathways were improved or created, the life quality of the residents improved and the mortality rate decreased, contributing to cultural, social and economic aspects. This work aims to present aspects that make sidewalks difficult to use in Manaus and, according to this research, reveals the accessibility measures required for the observed problems, for fluidity, comfort and safety during the pedestrian's journey. Considering these arguments, this study conducted bibliographic surveys and questionnaires with several pedestrianized areas of the cities, emphasizing social, physical, cultural and environmental factors. Through this research, problems were identified in relation to the structure, the carelessness of local residents and traders improperly situated on the sidewalks. With the data acquired, it was possible to elaborate a scheme with possible solutions that meets the needs of all citizens, with an appropriate lighting, accessibility, convenience and sustainability system.
\end{abstract}

Keywords: locomotion. pedestrian. sidewalks.

\section{INTRODUCTION}

The port area of Manaus, Brazil, was heavily populated until the mid-1970s; the population was limited to the south, center-south, west and center-west areas, but with Duty Free creation in Manaus in the $1980 \mathrm{~s}$, the city received strong immigration, mainly to the north and east. However, this intense process motivated a strong migration, new neighborhoods and irregular occupations within the infrastructure, due to the great population density. The extent of this advanced demographic growth has caused regions to be occupied in a disorderly way, bringing diverse flaws in relation to the city's infrastructure, as in the road system.

According to the Brazilian Transit Code [1], pedestrians are assured the use of sidewalks and passageways in urban streets and the shoulder of rural roads for circulation.

However, the city of Manaus has a great deficiency in its road system, mainly regarding pedestrians. This deficit is a result of several factors, whether due to the lack or neglect of structure, planning, pedestrian or driver infractions, or due to the intense weather of the region.

Research on the types of transportation usually overlooks the part of the trips that include walking. It is easier to collect data on vehicle movement such as traffic-flow rates and speed, and run tests for transportation models; walking is an invisible type of transportation for most of the transportation planners [2]. 
Walking offers several benefits to a community, including savings in transportation costs, improved quality of life, reduction of environmental impacts, greater equity of access to urban activities, etc.

New York, Holland, Helsinki, Sao Paulo and several other cities have adhered to a concept of urban planning that is aimed at the walkability of the pedestrian, which refers to how the city is planned so that there is fluidity, displacement and accessibility for pedestrians and non-motor vehicles. It aims at pedestrian mobility, but also brings benefits to the region.

The urbanist Jeff Speck [3, p. 4] states that walkability is both an end and a mean, as well as a measure. While the physical and social rewards of walking are many, walkability is perhaps most useful as it contributes to urban vitality and is most meaningful as an indicator of that vitality.

In this article, we will analyze the importance and the influence of the walkability in the traffic of Manaus, through bibliographical research and field analysis, with the objective of identifying the failures in the local sidewalk and then elaborate a plan of directives for the implementation and improvement of passageways and, consequently, the city.

\section{METHODOLOGY}

The applied methodology was carried out through a case study, for data collection, and the composition of the data obtained was performed through an interaction network.

The case study method is qualitative, since information is organized according to categories or levels. Its origin has several positions, as well as its utilities. It is known as a methodology or as a choice of a study goal by the interest in individual cases with the purpose of investigating a specific case contextualized in a time and place.

It is based on several questions that seek the reason behind a place. In its composition, a bibliographic search is necessary for better understanding the acquired data and comparison over the years.

According to Gil [4], the case study does not accept a rigid script for its delimitation, but it is possible to define four phases that show its delineation: a) delimitation of the unit-case; b) data collection; c) selection, analysis and interpretation of data; and d) creation of the report.

The network of interactions is also a qualitative method, which consists of the representation of follow-up projects, designed to allow the identification of direct impacts (secondary, tertiary, etc.) and their interactions, making use of graphs, flowcharts or diagrams.

According to Warner and Preston [5], interaction networks work from an activity list to establish cause, condition and effect relationships. They are an attempt to recognize that a series of impacts can be triggered by a single action. Generally, they define a set of possible interaction networks and allow the user to identify the impacts by selecting and sequencing the appropriate actions of a project.

Through the identification of cause and effect it is possible to identify the reasons for how the problem arose and find solutions to its consequences, analyzing more clearly the origin and the impacts caused by the problem.

A route was analyzed and chosen because of its reasonable length for all those who proposed to be analyzed and for having different pathways (local and collector). Pedestrian patterns were analyzed in various situations in a single route. The path has a distance of 2 $\mathrm{km}$ and starts in Tapajós Street, no. 327, CEP 69010-150, downtown, and ends in Sete de Setembro Avenue, in front of the Federal Institute of Education, Science and Technology of Amazonas (IFAM), no. 1975, CEP 69020-120, also in downtown area. 
Table 1: Data for the volunteers that carried out the proposed course.

\begin{tabular}{|l|l|l|l|l|}
\hline Volunteers & Age & Physical analysis & Health analysis & Observations \\
\hline Pedestrian 1 & 12 & $\begin{array}{l}\text { Overweight, } \\
\text { considered healthy }\end{array}$ & Practice exercises & $\begin{array}{l}\text { Finished the route fast, but } \\
\text { felt a little tired }\end{array}$ \\
\hline Pedestrian 2 & 20 & $\begin{array}{l}\text { No restrictions, } \\
\text { considered healthy }\end{array}$ & No orientations & Finished the route calmly \\
\hline Pedestrian 3 & 48 & $\begin{array}{l}\text { Sciatic, considered } \\
\text { healthy }\end{array}$ & $\begin{array}{l}\text { Does not walk much } \\
\text { nor take stairs }\end{array}$ & $\begin{array}{l}\text { Finished the route in a longer } \\
\text { time and more tiringly }\end{array}$ \\
\hline Pedestrian 4 & 71 & $\begin{array}{l}\text { Rheumatism, } \\
\text { considered healthy }\end{array}$ & Walks slowly & $\begin{array}{l}\text { Finished the route in a long } \\
\text { time, tiringly, and with } \\
\text { difficulty }\end{array}$ \\
\hline
\end{tabular}

The route begins with walking from Tapajós St. to Joaquim Nabuco Ave. and to Sete de Setembro Ave., which were walked in the morning, at 7:00 am, during rush hour. And then, in the afternoon, at 5:00pm, also in rush hour, walkers return from Sete de Setembro Ave. to Joaquim Nabuco Ave. and to Tapajós St.

The pedestrians were selected from several characteristics, and three indicatives were used for the evaluation: age, physical analysis (considering, for instance, difficulties in walking, whether the pedestrian uses a wheelchair, is blind, etc.) and a health analysis (whether the individual in question has any medical restrictions or guidance issues, for instance, not being able to walk for a long time).

Then, the difficulties encountered along the way were analyzed according to the volunteers, as shown in Table 2.

Table 2: Difficulties encountered by pedestrians.

\begin{tabular}{|l|l|l|}
\hline Diagnosis author & Difficulty & Observations \\
\hline Pedestrian 3 & Uneven footsteps & $\begin{array}{l}\text { The unevenness is considerable and has already been } \\
\text { the cause of several accidents. }\end{array}$ \\
\hline Pedestrian 4 & Holes in sidewalks & $\begin{array}{l}\text { Wastage in sidewalks is evident and holes are more } \\
\text { frequent. }\end{array}$ \\
\hline Pedestrian 2 & $\begin{array}{l}\text { Ramps with inappropriate } \\
\text { inclinations or their } \\
\text { absence }\end{array}$ & $\begin{array}{l}\text { The absence of ramps in streets is frequent, from 15 } \\
\text { found stairs along the way, 4 present ramps and } 1 \\
\text { presents inappropriate inclination. Even though } \\
\text { accessibility is greatly debated, it is still hard to see it } \\
\text { in practice. }\end{array}$ \\
\hline Pedestrian 1 & $\begin{array}{l}\text { Sidewalk obstruction } \\
\text { (cars, bush, vending } \\
\text { tends, restaurant tables) }\end{array}$ & $\begin{array}{l}\text { Through the route, there were various detours due to } \\
\text { obstructions where it was supposed to be free. }\end{array}$ \\
\hline Pedestrian 2 & Absence of sidewalks & $\begin{array}{l}\text { In specific routes, the passer-by is forced to walk on } \\
\text { the road due to the absence of sidewalks. }\end{array}$ \\
\hline Pedestrian 3 & Absence of illumination & $\begin{array}{l}\text { It was observed during the route few light posts were } \\
\text { available, presenting risks to pedestrian safety. }\end{array}$ \\
\hline Pedestrian 4 & Absence of accessibility & $\begin{array}{l}\text { It is almost unfeasible for wheelchair users, injured } \\
\text { citizen, or even someone pushing a stroller to perform } \\
\text { the route, since when ramps are available, there is } \\
\text { appropriate inclination, when they are not, pedestrians } \\
\text { are forced to use the road. }\end{array}$ \\
\hline Pedestrian 4 & $\begin{array}{l}\text { Route greatly tiring due } \\
\text { to the weather }\end{array}$ & $\begin{array}{l}\text { It is exhausting to walk by foot due to the weather. } \\
\text { holes and wreckage in the way. }\end{array}$ \\
\hline Lack of adequate paving & Uneven paving in street sign area or near to them. \\
\hline
\end{tabular}


Table 3: Zones and projects analyzed by the metropolitan area of Manaus.

\begin{tabular}{|l|l|l|}
\hline Area & Population & Projects \\
\hline South & 286.488 & $25.30 \%$ \\
\hline North & 501.055 & $22.70 \%$ \\
\hline Central-south & 152.753 & $11.40 \%$ \\
\hline West & 253.589 & $10.40 \%$ \\
\hline Central-west & 148.333 & $7.90 \%$ \\
\hline East & 392.599 & $22.30 \%$ \\
\hline
\end{tabular}

After the case study, a comparison was made with the data obtained from the last censuses carried out by the Brazilian Institute of Geography and Statistics (IBGE) [7] and the Brazilian Service of Support to Micro and Small Businesses (SEBRAE) [8] versus the number of urban enterprises, with the objective of identifying the characteristics of the urban elements that favor commuting by motor vehicles. According to Helbing et al. [9], patterns of movement of pedestrian crowds are predictable, although there are individual preferences, aims and destinations in effect.

\section{ANALYSIS OF PEDESTRIAN MOBILITY FACTORS IN MANAUS, BRAZIL}

Some pedestrians do not notice any difficulties; but this differs throughout the age group, because the restrictions caused by the paths change over time [10].

When analyzing Table 1 together with Table 2, it is possible to notice that the same course presents different difficulties for each individual, and that the age group and physical restrictions, for example, point to the problems encountered on route according to the individual's needs.

When a child is at an age where they are able to walk, but too young to go out on the street without accompaniment, they walk along the path holding an adult's hand and they walk side by side. Therefore, the route space must be greater for them to walk in such a way.

In adulthood, physical issues are not the biggest problem, but lack of attention, such as cell-phone use while walking, or the habit of not looking directly forward, brings great risks. A path with holes, for example, can easily be passed unnoticed, causing a stumble.

For the elderly walking, again there should be no holes in the crossings, nor many slopes or ramps and, moreover, the journey time is longer. In Table 2, we can see the reasons for the lack of footpaths being in a good condition for pedestrians and sidewalks do not fulfill their real function of assisting in locomotion.

The General Theory of Walkability explains how, to be favored, a walk has to satisfy four main conditions: it must be useful, safe, comfortable and interesting. Each of these qualities is essential, none alone is sufficient. Useful means that most aspects of daily life are located close to hand and organized in a way that walking serves them well. Safe means that the street has been designed to give pedestrians a fighting chance against being hit by automobiles; they must not only be safe but also feel safe, which is even tougher to satisfy. Comfortable means that buildings and landscape shape urban streets into 'outdoor living rooms', in contrast to wide-open spaces, which usually fail to attract pedestrians. Interesting means that sidewalks are lined by unique buildings with friendly faces and that signs of humanity abound [3, p. 11].

From the obstacles found it was possible to study them in search of their origins and for suitable solutions; it is noted that the problems are related to the structure or planning, inspection or standardization, and accessibility and sustainability. 


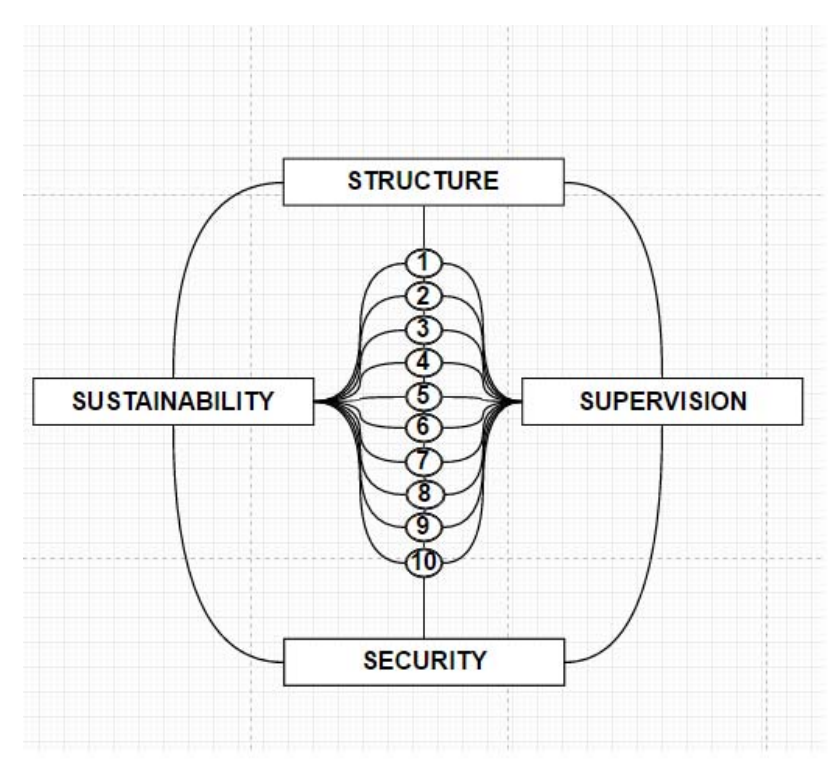

Figure 1: Problem Interaction Network pointed out by volunteers. (Source: Luísa Nascimento, 2017.)

In Table 3, it is possible to compare two zones of Manaus, the South and the North Zones. It is observed that the first one has more urban enterprises - this means that it has more hospitals, police stations and supermarkets - and the second one is larger in number of inhabitants. To explain the walkability of a neighborhood, primary measures have been used as operational indicators, such as density, connectivity, proximity to main destinations. It is also a strong assumption that indicators such as imageability or enclosure, which are difficult to measure, are significant factors affecting livelihood on the streets [11], [12].

Incoherence in housing and service centers is notorious, and a lack of integration between the city's regions influences longer displacements, where it becomes unfeasible to carry them out on foot. Places that should have more services for the locals are occupied by a large amount of residences, without space to other services.

Greater availability and ease to find support centers necessary to citizens in their own area encourages them to remain, rather than move away, and to refrain from using motor vehicles, causing fuel economy or not buying bus tickets. Urban environment adaptations enable better quality of life; for instance, the pedestrian adaptation focused lanes, which are aimed at less displacement. In other words, narrower streets, with more vegetation, more comfort in city parks, among others, that generate connectivity among neighborhoods, population density increase, sustainability, life quality, and housing diversification, where people of different social class, race, age, create bonds that are fundamental to the city development.

City development is connected, in several aspects, to pedestrian mobility, since it has a great influence in its growth. It is also noteworthy that for a city to become more walkable, it is not enough to have a structured system of roads; the resident incentives are indispensable, with pleasant roads, beautiful landscapes, benches and some coverage for the pedestrian, for example. 
Table 4: Possible solutions found for the volunteers' diagnosis.

\begin{tabular}{|c|c|c|}
\hline Number & Problem & Solution \\
\hline 1 & Uneven footsteps & $\begin{array}{l}\text { Supervision of sidewalks and penalties for } \\
\text { lot owners due to the lack of } \\
\text { standardization of sidewalks and } \\
\text { awareness events. }\end{array}$ \\
\hline 2 & Sidewalk holes & $\begin{array}{l}\text { Paving with laid cement or concrete, } \\
\text { hydraulic tile, or interlocked pavement. }\end{array}$ \\
\hline 3 & $\begin{array}{l}\text { Ramps with inappropriate } \\
\text { inclinations or their absence }\end{array}$ & $\begin{array}{l}\text { Creation of ramps and adjustment to } \\
\text { existing ones with declivity to } 2 \% \text {. }\end{array}$ \\
\hline 4 & $\begin{array}{l}\text { Sidewalk obstruction (cars, bush, } \\
\text { vending tends, restaurant tables) }\end{array}$ & $\begin{array}{l}\text { Supervision of sidewalks and penalties for } \\
\text { lot owners due to the lack of } \\
\text { standardization of sidewalks and } \\
\text { awareness events. }\end{array}$ \\
\hline 5 & $\begin{array}{l}\text { Pedestrians walking on the roads and } \\
\text { accidents }\end{array}$ & $\begin{array}{l}\text { Creation of areas that separate vehicular } \\
\text { and pedestrian traffic for better public and } \\
\text { individual safety (bicycle lanes, pedestrian } \\
\text { lanes). }\end{array}$ \\
\hline 6 & Dark streets and no policing & $\begin{array}{l}\text { Implantation of lighting poles, programs } \\
\text { that integrate society with local authorities } \\
\text { and awareness of the public patrimony. }\end{array}$ \\
\hline 7 & $\begin{array}{l}\text { Sidewalks lacking required care to } \\
\text { the elderly, wheelchair users, visually } \\
\text { impaired and injured citizens }\end{array}$ & $\begin{array}{l}\text { Promote an accessible structure for all. } \\
\text { There are several companies that specialize } \\
\text { in projects like these, such as Design for } \\
\text { All Foundation. }\end{array}$ \\
\hline 8 & Damaged sidewalks & $\begin{array}{l}\text { Perform analysis on the material used, the } \\
\text { best cost } X \text { benefit, more suitable materials } \\
\text { (drainage boards, limestone, among others) } \\
\text { and keep the landscaping present for the } \\
\text { water flow. }\end{array}$ \\
\hline 9 & Route very hot due to the weather & $\begin{array}{l}\text { In addition to the vegetation and roofs used } \\
\text { to design shade, the implantation of public } \\
\text { drinking fountains scattered throughout the } \\
\text { city are essential for a good walk. }\end{array}$ \\
\hline 10 & $\begin{array}{l}\text { Lack of appropriate paving for } \\
\text { visually impaired citizens }\end{array}$ & $\begin{array}{l}\text { Regular, stable and non-slip flooring under } \\
\text { all conditions, expansion joints and covers, } \\
\text { sidewalks could be lowered or raised, } \\
\text { tactile signaling, directional tactile floor, } \\
\text { among other components that facilitate } \\
\text { signaling. }\end{array}$ \\
\hline 11 & $\begin{array}{l}\text { Lack of appropriate signs for } \\
\text { disabled citizens }\end{array}$ & $\begin{array}{l}\text { Supervision of sidewalks and tactile } \\
\text { pavement, as well as wider lanes for } \\
\text { wheelchair-user access. }\end{array}$ \\
\hline
\end{tabular}

\section{CONCLUSIONS}

Walking patterns have a great influence on the road systems of a city and provide interactions of different means. Non-motorized mobility is performed by most citizens, even if it is only for a moment. With the information and analysis obtained, it is noticed that the displacements by the city reflect the social, cultural and economic citizen 
characteristics. And how they are targeted is influential in urban activities, providing area characterization of the city and the profiles of the region residents.

Pedestrian locomotion care is, unfortunately, not the most ideal way for accessibility to be improved for all, but the implementation of measures and new methods do allow for more safety and comfort when walking through the city, as well as providing improvements in the pavement itself. And the road system quality provides the urban environment with social, cultural and environmental improvements. Structure and planning are very important aspects when making a city walkable, including ways that aim for the least displacement and measures that encourage the residents to opt for walking more often. Urban service provision such as supermarkets, hospitals and police stations, in a similar way to the population distribution, avoid the displacement of people to more distant areas, responsible for most urban displacement.

It is necessary to meet the citizen's needs, when considering the accessibility, fluidity and comfort of residents. Therefore, to obtain better road system operational efficiency, considering its various urban functions and variations of its physical characteristics, it is required to establish a plan that governs activities and traffic on the public highway and the use and place occupation.

\section{REFERENCES}

[1] Código de Trânsito Brasileiro (CTB), Article 68, Chapter IV. See decree no. 2327, 1997. Duration Law no. 13.281, 2016.

[2] Litman, T.A., Economic Value of Walkability, Vol. 10, Victoria, 2011.

[3] Speck, J., Walkable City: How Downtown Can Save America, One Step at a Time, Macmillan: New York, 2012.

[4] Gil, A.C., Como Elaborar Projetos e Pesquisa, 3rd ed., Atlas: São Paulo, p. 58, 1995.

[5] Warner, M.L. \& Preston, E.H., Review of Environmental Impact Assessment Methodologies, United States Environmental Protection Agency: Washington D.C, 1974.

[6] Melo, R., Métodos de avaliação de impactos ambientais, Master's dissertation, Federal University of Paraiba, Paraíba, Brazil, 2010. www.ufpb.br./metodos avaliacao_impactos_ambientais.pdf. Accessed on: Nov. 2016.

[7] Instituto Brasileiro de Geografia e Estatítica (IBGE), Censo 2010, Amazonas, Brazil. http://censo2010.ibge.gov.br. Accessed on: Nov. 2016.

[8] Serviço Brasileiro de Apoio às Micro e Pequenas Empresas (SEBRAE), Censo empresarial, cidade de Manaus 2010, Amazonas, Brazil. https://www.sebrae.com.br. Accessed on: Nov. 2016.

[9] Helbing, D., Molnár, P., Farkas, I.J. \& Bolay, K., Self-organizing pedestrian movement. Environment and Planning B: Planning and Design, 28(3), pp. 361-383, 2001.

[10] Gold, P.A., Melhorando as condições de caminhada em calçadas. Nota Técnica, Gold Projec, Amazonas, Brazil, 2013. http://docslide.com.br/documents/cartilha-spphilip-anthony-gold.html. Accessed on: Nov. 2016.

[11] Ewing, R. \& Handy, S., Measuring the unmeasurable: Urban design qualities related to walkability. Journal of Urban Design, 14(1), pp. 65-84, 2009.

[12] Ewing, R., Handy, S., Brownson, R.C., Clemente, O. \& Winston, E., Identifying and measuring urban design qualities related to walkability. Journal of Physical Activity and Health, 3(1), pp. 223-240, 2006. 